\title{
LUZ NATURAL E CONCENTRACÕES DE SACAROSE NO CULTIVO IN VITRO DE Cattleya walkeriana
}

\author{
Sunlight and sucrose concentrations on in vitro culture of Cattleya walkeriana
}

\author{
Samantha Léa Dignart ${ }^{1}$, Evaristo Mauro de Castro ${ }^{2}$, Moacir Pasqual ${ }^{3}$, \\ Alessandro Ferronato ${ }^{4}$, Francyane Tavares Braga ${ }^{5}$, Renato Paiva ${ }^{6}$
}

\begin{abstract}
RESUMO
Cattleya walkeriana é uma das mais apreciadas orquídeas do mundo, possuindo grande valor ornamental. A micropropagação é uma importante ferramenta para reprodução dessa espécie. Pelos altos custos de produção através da micropropagação convencional, relacionados à perdas durante aclimatização e alto consumo de energia em salas de crescimento, objetivou-se com este trabalho avaliar estratégias alternativas no cultivo in vitro. Foram testados dois diferentes fatores, sendo eles luz (em sala de crescimento convencional, casa de vegetação com sombreamento de $50 \%$, e casa de vegetação sem sombreamento) e concentrações de sacarose $\left(0,15\right.$ e 30 g.L $\left.\mathrm{L}^{-1}\right)$. O material se constitui de plântulas previamente germinadas in vitro, em meio MS e cultivadas em sala de crescimento por 90 dias. Luz natural em casa de vegetação, resultou em aumento no número de brotos, na espessura foliar e na frequiência e diâmetro dos estômatos, e ocasionou diminuição do comprimento das plântulas e dos teores de clorofila. Um menor número de raízes e brotações foram formados na concentração de $15 \mathrm{~g} . \mathrm{L}^{-1}$ de sacarose. A ausência de sacarose resultou em menores teores de clorofila. Pela análise dos resultados, foi possível concluir que o ambiente de cultivo altera as respostas de plântulas cultivadas in vitro e pode-se recomendar o uso da luz natural e redução nas concentrações de sacarose pela metade para a micropropagação de Cattleya walkeriana, observandose a fase da propagação e os objetivos da mesma.
\end{abstract}

Termos para indexação: Orquídea, micropropagação, anatomia

\begin{abstract}
Cattleya walkeriana is one of the most important orchids in the world and has high ornamental value. Micropropagation plays an important role in the reproduction of this species. Based on high production costs of the standard micropropagation regarding the losses during acclimatization and high energy consumption in growth chambers, this paper aimed at evaluating alternative strategies for the in vitro cultivation. Two different factors were tested: light (standard growth chamber, greenhouse with 50\% shading, and greenhouse without shading) and sucrose concentrations $\left(0,15\right.$, and $\left.30 \mathrm{~g} \cdot \mathrm{L}^{-1}\right)$. The material was composed by plantlets previously germinated in vitro on MS medium and cultivated in a growth chamber for 90 days. Natural light in greenhouse induced an increase in the number of shoots, leaf thickness, stomata frequency and diameter and, on the other hand, caused decrease in the plantlet length and chlorophyll levels. Lower number of roots and shoots were formed at the concentration of $15 \mathrm{~g} . \mathrm{L}^{-1}$ sucrose. The absence of sucrose resulted in lower chlorophyll levels. Based on these results, it was possible to conclude that the cultivation environment modifies the response of in vitro cultivated plantlets and the natural light and reduction of sucrose concentrations by half can be recommend for the micropropagation of Cattleya walkeriana, taking in consideration the propagation phases and their goals.
\end{abstract}

Index terms: Orchid, light, micropropagation, anatomy.

(Recebido em 9 de março de 2006 e aprovado em 26 de março de 2007)

\section{INTRODUÇÃO}

As plantas da família Orchidaceae são as mais evoluídas do reino vegetal (PAULA \& SILVA, 2001). As catléias, em razão da estrutura de suas flores, podem ser ligadas a muitos outros gêneros e híbridos de flores exuberantes e por isso são as orquídeas mais comercializadas na atualidade, o que lhes confere considerável importância econômica (ZANENGA-GODOY

\footnotetext{
${ }^{1}$ Mestre em Agronomia-Fisiologia Vegetal - Instituto de Ciências Biológicas/ICB - Centro Universitário de Várzea Grande/UNIVAG - Avenida Dom Orlando Chaves, 2655 - Cristo Rei - 78118-000 - Várzea Grande, MT - leadigart@yahoo.com.br

${ }^{2}$ Professor Adjunto IV, Doutor em Agronomia Fitotecnia - Departamento de Biologia/DBI - Universidade Federal de Lavras/UFLA - Cx. P. 3037 - $37200-000$ Lavras, MG - emcastro@ufla.br

${ }^{3}$ Professor Titular, Doutor em Melhoramento Genético de Plantas - Departamento de Agricultura/DAG - Universidade Federal de Lavras/UFLA - Cx. P. 3037 37200-000 - Lavras, MG - mpasqual@ufla.br

${ }^{4}$ Mestre em Agricultura Tropical - Departamento de Biologia/DBI - Centro Universitário de Várzea Grande/UNIVAG - Avenida Dom Orlando Chaves, 2655 Cristo Rei - 78118-000 - Várzea Grande, MT

${ }^{5}$ Bióloga, Doutoranda em Agronomia Fitotecnia- Departamento de Agricultura/DAG - Universidade Federal de Lavras/UFLA - Cx. P. 3037 - $37200-000$ Lavras, MG - ftbraga@yahoo.com.br

${ }^{6}$ Doutorado em Agronomia - Departamento de Biologia/DBI - Universidade Federal de Lavras/UFLA - Campus Universitário - Setor de Fisiologia Vegetal Cx. P. 3037 - 37200-000 - Lavras, MG - renpaiva@ufla.br
} 
\& COSTA, 2003). Embora o cultivo de orquídeas tenha contribuído para tornar o Brasil conhecido internacionalmente por suas plantas exóticas, elas foram obtidas, quase sempre, através do extrativismo predatório das matas tropicais (KÄMPF, 1997).

As técnicas de cultura de tecidos, entre as quais a micropropagação, representa uma alternativa para contornar obstáculos que limitam a propagação convencional de espécies (TORRES \& CALDAS, 1998). Os altos custos na produção de mudas por cultura de tecidos, entre outros fatores, relacionam-se ao alto consumo de energia elétrica nos laboratórios, principalmente em salas de crescimento (ERIG \& SCHUCH, 2005; GRATTAPAGLIA \& MACHADO, 1998; KODYM \& ZAPATA-ARIAS, 1999; SAVANGIKAR, 2004; BRAGA, et al., 2009), e à baixa eficiência de aclimatização por causa da heterotrofia dos tecidos cultivados, resultantes do ambiente imposto pelas condições de cultivo in vitro (ARIGITA et al., 2002; KOZAI \& KUBOTA, 2001). Entre os fatores relacionados à condição heterotrófica das plantas in vitro, destaca-se (ECONOMOU \& READ, 1987; IBARAKI \& NOZAKI, 2005) a adição de fonte externa de luz e carboidrato ao meio de cultura (KOZAI et al., 1991; PRAKASH et al., 2004; REZENDE et al., 2008; SANTANAet al., 2008; SERRET et al., 1997). Essa condição de cultivo, resulta em diversas alterações morfológicas e fisiológicas de plântulas cultivadas in vitro, que são responsáveis por grande parte das perdas durante a aclimatização.

Objetivou-se otimizar o cultivo in vitro de $C$. walkeriana, utilizando-se fonte luz natural, avaliando diferentes concentrações de sacarose adicionadas ao meio de cultura.

\section{MATERIALE MÉTODOS}

O material vegetal consistiu de plântulas de orquídeas da espécie Cattleya walkeriana Gardn, oriundas de sementes germinadas in vitro, em meio MS, sendo selecionadas aquelas entre 0,3 e $0,5 \mathrm{~cm}$ de altura, contendo de 1 a 3 raízes. O cultivo foi feito em meio MS, acrescido de $6 \mathrm{~g} . \mathrm{L}^{-1}$ de agar, $\mathrm{pH} 5,8$ antes da autoclavagem.

$\mathrm{O}$ experimento constou de três concentrações de sacarose $(0,0 ; 15,0 ;$ e 30,0 g.L-1) e foi conduzido em casa de vegetação com dois diferentes níveis de luminosidade, com e sem sombreamento, que foram obtidos através de telas de nylon (50\%), e em sala de crescimento, com fotoperíodo de 16 horas, temperatura de $25 \pm 2^{\circ} \mathrm{C}$, com densidade de fluxo de fótons de $5,52 \mathrm{~W} \cdot \mathrm{m}^{-2} \cdot \mathrm{s}^{-1}$, fornecida por lâmpadas brancas fluorescentes para servirem como tratamento-controle.

Caracterização do ambiente: a radiação em casa de vegetação foi mensurada em dias típicos da estação utilizando-se sensores de radiação acoplados a um sistema de registro (LI 1400; Licor. Neb). Foi determinada a transmitância de cada cobertura e, a partir dos dados da estação Climatológica da UFLA, estimou-se a radiação diária de todo período amostral. A temperatura foi avaliada, durante um mês, através de um termo-higrômetro (RMR132HG; Oregon Scientific). Foram registradas temperaturas máximas e mínimas diárias e a média do dia foi feita pelo padrão do Instituto Nacional de Meteorologia (INMET). Procedeu-se com elaboração de uma curva de regressão entre os valores estimados em casa de vegetação e na estação climatológica da UFLA. A equação de regressão foi utilizada para estimar a temperatura de todo o período amostral.

Após 90 dias de cultivo, o experimento foi avaliado utilizando as seguintes variáveis: Características morfológicas: número de brotações, número de folhas e raízes por plântula, comprimento da parte aérea $(\mathrm{cm})$ e comprimento médio das raízes $(\mathrm{cm})$.

Quantificação dos teores de clorofila: Foram utilizadas três amostras de $0,5 \mathrm{~g}$, de tecido foliar fresco, que foram maceradas em $30 \mathrm{ml}$ de cetona $80 \%$. As concentrações de clorofila foram determinadas pelo método de Arnon (1949), com base em leituras no espectrofotômetro de luz a comprimentos de onda definidos em 663 e $645 \mathrm{~nm}$.

Características anatômicas: Foram coletadas as folhas de número 2, contando-se a partir do ápice. Utilizouse micrótomo de mesa para a obtenção de seções transversais Os cortes paradérmicos foram realizados manualmente e feitos no terço mediano da folha. As seções foram clarificadas em hipoclorito de sódio $5 \%$ e coradas numa mistura de azul de astra e safranina (KRAUS \& ARDUIM, 1997). As seções paradérmicas foram coradas com solução de safranina $1 \%$. Utilizou-se glicerina $50 \%$ para montagem das lâminas, e as fotomicrografias foram feitas ao microscópio Olympus BX-60 no aumento de 40x.

O número de estômatos foi determinado de acordo com a metodologia de Laboreau et al. (1961), sendo utilizados quatro campos de cinco indivíduos por tratamento, para a determinação da densidade estomática e mensuração da espessura das epidermes, do mesofilo e da espessura total do limbo foliar. As determinações de espessura foram realizadas utilizando-se uma ocular micrométrica acoplada em microscópio de luz com aumento de 40x.

Delineamento experimental e análise estatística: Delineamento inteiramente casualizado (DIC), em esquema fatorial 3X3 (luz X sacarose), totalizando 9 tratamentos com 10 repetições, onde cada repetição continha 5 plântulas. Os frascos foram fechados com tampa de 
polipropileno vedada com parafilme. Não houve problemas relevantes de contaminação. Os dados foram submetidos à análise de variância, sendo que o coeficiente de variação foi igual ou superior a $20 \%$ e utilizou-se transformação $\sqrt{x}$ ou $\log . \mathrm{x}+1$. As médias foram comparadas pelo teste de Tukey, a $5 \%$.

\section{RESULTADOS E DISCUSSÃO}

Caracterização do ambiente: Foi observada uma média de temperatura de $21,74^{\circ} \mathrm{C}$, sendo a temperatura mínima observada de $16,94^{\circ} \mathrm{C}$, e a máxima de $23,66^{\circ} \mathrm{C}$. A técnica de substituição da fonte de luz artificial para luz natural é ainda muito questionada por causa da escassez de informações sobre os efeitos que a luz natural causa nas culturas. Um dos fatores que provoca tal questionamento é o aumento e oscilação da temperatura dentro dos frascos de cultivo; contudo Ahloowalia \& Savangikar (2004) afirmam que muitas plântulas cultivadas in vitro são capazes de tolerar altas flutuações de temperatura e se adaptam melhor às condições de campo, quando aclimatizadas, do que aquelas que são cultivadas sempre sob a mesma temperatura. Os valores de radiação recebidos no ambiente de casa de vegetação, foram em média 3,16 MJ.m ${ }^{-2}$, para cada dia dentro da casa de vegetação, e de 1,33 MJ.m-2, em cada dia em casa de vegetação, sob a tela de nylon.

Características morfológicas: Não foram observadas interações significativas dos fatores luz e sacarose para essas características. Os resultados obtidos em diferentes condições de luz e diferentes concentrações de sacarose para número de folhas, número de brotações e de raízes, comprimento de parte aérea e comprimento médio de raízes, estão apresentados na Tabela 1 .
O número de brotos foi maior para plântulas mantidas em sala de crescimento e em casa de vegetação sem sombrite do que em casa de vegetação com sombreamento. Kodym \& Zapata-Arias (1999) afirmam que além dos reguladores de crescimento, a luz também influencia consideravelmente a taxa de multiplicação e o crescimento de explantes cultivados in vitro. Esses autores observaram que o número de brotos por explante de bananeira foi maior sob luz natural, do que sob o cultivo convencional com iluminação artificial. Uma provável explicação para elevação nas taxas de multiplicação na luz solar, é que a intensidade de luz elevada poderia estar reduzindo as concentrações de auxinas endógenas das gemas através da fotoxidação, provocando um deslocamento do balanço hormonal em direção às citocininas (RADMANN et al., 2001; SOONTOUNCHAINAKSAENG et al., 2001).

Os tratamentos de luz não influenciaram a quantidade e comprimento de raízes por plântula. Radmann et al. (2001) também afirmam que para Gypsophila paniculata as intensidades luminosas utilizadas, durante a fase de multiplicação, não afetaram o enraizamento.

O comprimento da parte aérea das plantas foi maior em sala de crescimento. Radman et al. (2001) observaram que o maior crescimento dos brotos pode ser o resultado do processo de estiolamento induzido pela luminosidade deficiente, ocasionando um maior crescimento dos entrenós com caules mais finos. Kozai et al. (1995) relatam que, em plântulas de batata cultivadas in vitro, ocorreu uma redução no alongamento de entrenós, para intensidade luminosa de $140 \mu \mathrm{mol} . \mathrm{m}^{-2} \cdot \mathrm{s}^{-1}$, comparados à intensidade de 70 $\mu \mathrm{molm}{ }^{-2} \cdot \mathrm{s}^{-1}$. Soontounchainaksaeng et al. (2001) afirmam que o crescimento das plantas é controlado por uma

Tabela 1 - Número de brotações (NB); Número de raízes (NR); Comprimento Médio de Raízes (CR) (cm); Comprimento de parte aérea $(\mathrm{CPA})(\mathrm{cm})$ e Número de folhas (NF) em diferentes ambientes de luz e concentrações de sacarose. Dados transformados em $\sqrt{x}$.

\begin{tabular}{|c|c|c|c|c|c|}
\hline Ambiente de Luz & NB & NR & CR & CPA. & $\mathrm{NF}$ \\
\hline Sala de Crescimento & $2,73^{A}$ & $4,31^{\mathrm{A}}$ & $1,35^{\mathrm{A}}$ & $2,00^{\mathrm{A}}$ & $12,69^{\mathrm{A}^{*}}$ \\
\hline Sombrite $50 \%$ & $2,14^{\mathrm{B}}$ & $4,26^{\mathrm{A}}$ & $1,18^{\mathrm{A}}$ & $1,69^{\mathrm{B}}$ & $11,99^{\mathrm{A}}$ \\
\hline Sem Sombrite & $2,75^{\mathrm{A}}$ & $4,34^{\mathrm{A}}$ & $1,24^{\mathrm{A}}$ & $1,37^{\mathrm{C}}$ & $11,17^{\mathrm{A}}$ \\
\hline \multicolumn{6}{|l|}{ Sacarose } \\
\hline Sem sacarose & $1,72^{\mathrm{B}}$ & $2,92^{\mathrm{C}}$ & $1,31^{\mathrm{A}}$ & $1,57^{\mathrm{A}}$ & $8,83^{\mathrm{B}^{*}}$ \\
\hline 15 g.L $\mathrm{L}^{-1}$ de sacarose & $2,88^{\mathrm{A}}$ & $4,14^{\mathrm{B}}$ & $1,26^{\mathrm{A}}$ & $1,78^{\mathrm{A}}$ & $13,16^{\mathrm{A}}$ \\
\hline 30 g. $\mathrm{L}^{-1}$ de sacarose & $3,02^{\mathrm{A}}$ & $5,86^{\mathrm{A}}$ & $1,19^{\mathrm{A}}$ & $1,71^{\mathrm{A}}$ & $13,85^{\mathrm{A}}$ \\
\hline $\mathrm{CV}$ & 10,32 & 9,02 & 11,43 & 15,19 & 13,02 \\
\hline
\end{tabular}

\footnotetext{
* Médias seguidas pela mesma letra não diferem entre si pelo teste de Tukey, a 5\%.
} 
série de reguladores de crescimento, como a auxina, que é sensível a elevadas intensidades de luz, podendo provocar uma alteração no balanço hormonal.

Nas diferentes concentrações 15,0 e 30,0 g. $\mathrm{L}^{-1}$ de sacarose, obtiveram-se resultados similares para número de folhas, número de brotos e comprimento de parte aérea (Tabela 1) das plântulas. Com base nesse resultado pode-se afirmar que, no cultivo in vitro de Cattleya walkeriana, é possível utilizar tanto a concentração convencional de sacarose (30g. $\left.\mathrm{L}^{-1}\right)$ como a metade dessa. Por outro lado, Chu \& Ribeiro (2002) observaram que o número de folhas produzidas por gemas cultivadas in vitro de diferentes espécies de Dioscorea apresentou correlação positiva com a concentração de sacarose adicionada ao meio. Serret et al. (1997) observaram que durante o estágio de multiplicação de Gardenia jasminoides, as altas concentrações de sacarose no meio de cultura tiveram um efeito positivo no peso final das plântulas. Não foram observadas diferenças estatísticas para número de brotos por explante nas duas concentrações utilizadas, contudo em ausência de sacarose, a brotação foi prejudicada.

Kozai et al. (1991) afirmaram que na presença de fontes externas de carboidrato para os explantes, as plântulas se comportam de forma heterotrófica, podendo afetar o crescimento das mesmas, bem como resultar em morte durante a aclimatização. Isso porque o acúmulo de açúcares nas folhas inibe a fotossíntese. Com base nos resultados obtidos neste experimento, recomenda-se menores doses de sacarose adicionadas ao meio de cultivo, na fase de crescimento das plântulas, pois essas não apresentaram diferenças prejudiciais ao desenvolvimento nem no ambiente de sala de crescimento e nem em casa de vegetação.

Teores de clorofila: foram observadas interações significativas entre os fatores luz e sacarose para os teores de clorofila $b$ e clorofila total. Maior teor de clorofila $a$ foi obtido em sala de crescimento com $30 \mathrm{~g} \mathrm{~L}^{-1}$ de sacarose. Menores valores foram encontrados em plântulas mantidas em casa de vegetação sem sombreamento e sem sacarose (Tabela 2).

Diversos trabalhos têm reportado que, para muitas espécies, a presença de sacarose no meio de cultivo tem sido considerada a principal causa da redução nos teores de clorofila e conseqüentemente na fotossíntese; baixos níveis de sacarose no meio de cultura foram correlacionados com um potencial elevado de produção de carboidrato pelas vias fotossintéticas (ADELBERG et al., 1999; CHENEVARD et al., 1997; DENG \& DONNELLY, 1993; KANECHI et al., 1998; LEE et al., 1985). No presente trabalho, porém, esse padrão não foi observado.

Maior concentração de clorofila $b$ foi observada em casa de vegetação com sombrite e com 30 g.L.-1 de

Tabela 2 - Teores de clorofila ( $\mu$ g.g massa fresca) de plantas em diferentes ambientes de luz e concentrações de sacarose. Dados transformados em $\log \mathrm{x}+1$.

\begin{tabular}{|c|c|c|c|}
\hline \multirow[b]{2}{*}{ Ambiente de Cultivo } & \multicolumn{3}{|c|}{ Teores de Clorofila $\left(\mu \mathrm{g} . \mathrm{g}^{-1} \mathrm{MF}\right)$} \\
\hline & Clorofila $a$ & Clorofila $b$ & Clorofila Total \\
\hline \multicolumn{4}{|l|}{ Sala de Crescimento } \\
\hline $0,0 \mathrm{~g} \cdot \mathrm{L}^{-1}$ & $90,07^{\mathrm{A} \mathrm{a}^{*}}$ & $47,20^{\mathrm{A} \mathrm{a}}$ & $137,23^{\mathrm{A} \mathrm{a}}$ \\
\hline 15,0 g. $\mathrm{L}^{-1}$ & $108,17^{\mathrm{A} \mathrm{a}}$ & $59,98^{\mathrm{A} a}$ & $168,10^{\mathrm{Aa}}$ \\
\hline 30,0 g. $\mathrm{L}^{-1}$ & $122,37^{\mathrm{A} \mathrm{a}}$ & $68,32^{\mathrm{A} a}$ & $190,63^{\mathrm{A} \mathrm{a}}$ \\
\hline \multicolumn{4}{|c|}{ Casa de Vegetação Sombreada $50 \%$} \\
\hline 0,0 g. $\mathrm{L}^{-1}$ & $49,89^{\text {В b }}$ & $27,77^{\text {В а }}$ & $77,65^{\text {В b }}$ \\
\hline 15,0 g.. $\mathrm{L}^{-1}$ & $105,52^{\mathrm{A} \mathrm{a}}$ & $44,45^{\text {В а }}$ & $149,93^{\mathrm{A} \mathrm{a}}$ \\
\hline 30,0 g.. $\mathrm{L}^{-1}$ & $117,18^{\mathrm{A} \mathrm{a}}$ & $87,40^{\mathrm{A} \mathrm{a}}$ & $204,51^{\mathrm{A} \mathrm{a}}$ \\
\hline \multicolumn{4}{|c|}{ Casa de Vegetação Sem Proteção } \\
\hline $0,0 \mathrm{~g} \cdot \mathrm{L}^{-1}$ & $36,31^{\mathrm{Bc}}$ & $12,84^{\mathrm{B} \mathrm{b}}$ & $49,14^{\mathrm{Bc}}$ \\
\hline 15,0 g. $\mathrm{L}^{-1}$ & $70,77^{\mathrm{Ab}}$ & $50,54^{\mathrm{A} a}$ & $121,27^{\mathrm{Aa}}$ \\
\hline 30,0 g. $\mathrm{L}^{-1}$ & $64,55^{\text {A b }}$ & $32,91^{\mathrm{Ab}}$ & $97,44^{\mathrm{A} \mathrm{b}}$ \\
\hline $\mathrm{CV}$ & 3,22 & 7,21 & 3,69 \\
\hline
\end{tabular}

\footnotetext{
* Letras maiúsculas correspondem a intensidade de luz e minúsculas a concentraçõea de sacarose. Letras iguais não diferem entre
} si pelo teste de Tukey a 5\% de significância. 
sacarose no meio. Meio sem sacarose resultou em menor teor de clorofila $b$ em casa de vegetação sem sombrite. Os teores de clorofila total seguiram esse mesmo padrão como pode ser observado na Tabela 2. Alterações nos teores de clorofila total já têm sido descritos em outros trabalhos (LEE et al., 1985; SERRET et al., 1997).

Características anatômicas: Observou-se neste estudo que as folhas de $C$. wlakeriana são do tipo hipoestomática, com estômatos dos tipos anomocítico, tetracítico e ciclocítico sendo que essa classificação já descrita por Zanenga-Godoy \& Costa (2003) para $C$. walkeriana, em ambiente natural. Houve interações significativas entre os fatores luz e sacarose para as variáveis de densidade estomática e diâmetros polar e equatorial dos estômatos. Maiores densidades foram encontradas para os tratamentos em casa de vegetação sombreada $50 \%$ na ausência de sacarose e casa de vegetação sem proteção com 30g.L L $^{-1}$ de sacarose. Com 15 g. $L^{-1}$, o ambiente de luz não afetou a densidade estomática.

As concentrações de 15 ou 30 g.L. ${ }^{-1}$ de sacarose, não resultaram em diferenças no diâmetro equatorial dos estômatos mas quando o carboidrato foi omitido do meio, verificou-se um maior diâmetro em casa de vegetação com sombrite. A maior média para diâmetro polar dos estômatos foi observada em meio sem sacarose, mantido em casa de vegetação com sombrite (Tabela 3 ).

Cutter (1971) descreve que apesar da variabilidade estomática ser um fenômeno relacionado principalmente, à umidade relativa dentro dos frascos, a intensidade luminosa pode ter implicações nesse processo. Assim, de acordo com os resultados apresentados pode-se notar que as maiores densidades estomáticas estão geralmente associadas à alta irradiância.

Diversos autores têm relatado um aumento na densidade estomática em folhas oriundas do cultivo in vitro sobre aquelas observadas em ambiente natural (KHAN et al., 2002; LEE et al., 1988; SCIUTTI \& MORINI, 1995). Zanenga-Godoy \& Costa (2003) trabalhando com C. walkeriana, oriundas de ambiente natural, observaram uma densidade média de 38,87 de estômatos $\left(\mathrm{mm}^{2}\right)$, médias superiores foram observadas no presente estudo, comprovando que cultivo in vitro aumenta as frequiências dos estômatos.

Neste estudo, o mesofilo de C. walkeriana possui epiderme uniestratificada em ambas as faces da folha e parênquima clorofiliano com células de formato semelhante. Observou-se que os tratamentos de luz e sacarose resultaram em efeitos significativos sobre todas as características estruturais do limbo foliar, exceto sobre a espessura das células epidérmicas na face abaxial. Na epiderme adaxial, a luz teve um efeito significativo de redução para o tratamento mantido em casa de vegetação sem sombrite (Tabela 4), Meio sem adição de sacarose resultou em maior espessura dessa epiderme. As concentrações de 15 e 30 g.L L $^{-1}$ de sacarose não foram estatisticamente diferentes, contudo, notou-se uma tendência de redução na espessura, pelo aumento das concentrações adicionadas ao meio (Tabela 4 ).

Tabela 3 - Densidade estomática, diâmetros polar e equatorial dos estômatos ( $\mu \mathrm{m})$ de plantas em diferentes ambientes de luz e concentrações de sacarose. Dados não transformados.

\begin{tabular}{|c|c|c|c|}
\hline Ambiente de Cultivo & Densidade & $\mathrm{DE}$ & $\mathrm{DP}$ \\
\hline \multicolumn{4}{|l|}{ Sala de Crescimento } \\
\hline 0,0 g. $\mathrm{L}^{-1}$ & $89,39^{\mathrm{A} \mathrm{b}}$ & $27,02^{\mathrm{A} a b}$ & $28,28^{\mathrm{A} \mathrm{a}}$ \\
\hline 15,0 g. $\mathrm{L}^{-1}$ & $85,84^{\text {A a }}$ & $28,93^{\text {A a }}$ & $25,97^{\mathrm{A} \mathrm{b}}$ \\
\hline 30,0 g. $\mathrm{L}^{-1}$ & $72,82^{\mathrm{Ab}}$ & $29,63^{\mathrm{A} \mathrm{a}}$ & $25,81^{\mathrm{A} \mathrm{b}}$ \\
\hline \multicolumn{4}{|c|}{ Casa de Vegetação Sombreada $50 \%$} \\
\hline 0,0 g. $\mathrm{L}^{-1}$ & $111,29^{\mathrm{A} a}$ & $29,45^{\text {A a }}$ & $32,08^{\mathrm{A} \mathrm{a}}$ \\
\hline 15,0 g. $\mathrm{L}^{-1}$ & $90,58^{\mathrm{A} \mathrm{a}}$ & $27,31^{\mathrm{A} \mathrm{a}}$ & $29,63^{\mathrm{AB} a}$ \\
\hline 30,0 g. $\mathrm{L}^{-1}$ & $87,62^{\mathrm{A} \mathrm{b}}$ & $28,29^{\mathrm{A} \mathrm{a}}$ & $27,58^{\mathrm{B} \mathrm{ab}}$ \\
\hline \multicolumn{4}{|c|}{ Casa de Vegetação Sem Proteção } \\
\hline 0,0 g. $\mathrm{L}^{-1}$ & $92,35^{\mathrm{A} a b}$ & $26,08^{\mathrm{A} \mathrm{b}}$ & $29,27^{\mathrm{A} \mathrm{ab}}$ \\
\hline 15,0 g. $\mathrm{L}^{-1}$ & $95,90^{\text {A a }}$ & $28,35^{\mathrm{A} \mathrm{a}}$ & $30,85^{\mathrm{A} \mathrm{a}}$ \\
\hline 30,0 g. $\mathrm{L}^{-1}$ & $111,29^{\mathrm{A} \mathrm{a}}$ & $27,39^{\mathrm{A} \mathrm{a}}$ & $29,97^{\mathrm{A} \mathrm{a}}$ \\
\hline $\mathrm{CV}$ & 13,98 & 6,31 & 6,14 \\
\hline
\end{tabular}

* Médias seguidas pela mesma letra não diferem entre si pelo teste de Tukey, a 5\%. Densidade - Estômatos $/ \mathrm{mm}^{-2} \mathrm{e}$ DP - Diâmetro Polar; D.E - Diâmetro equatorial. 
Tabela 4 - Espessura dos tecidos foliares $(\mu \mathrm{m})$ em seções transversais de folhas em diferentes ambientes de luz e concentrações de sacarose. Dados não transformados.

\begin{tabular}{|c|c|c|c|c|}
\hline Ambiente de Cultivo & E. Ad & E.Ab & Meso & ETL \\
\hline \multicolumn{5}{|l|}{ Sala de Crescimento } \\
\hline 0,0 g. $\mathrm{L}^{-1}$ & $68,64^{\mathrm{A} \mathrm{a}}$ & $25,08^{\mathrm{A} \mathrm{a}}$ & $823,42^{\mathrm{A} \mathrm{a}}$ & $917,13^{\mathrm{A} \mathrm{a}}$ \\
\hline 15,0 g. $\mathrm{L}^{-1}$ & $66,12^{\mathrm{Aa}}$ & $23,22^{\mathrm{Aa}}$ & $651,57^{\mathrm{ABa}}$ & $740,11^{\mathrm{AB} a}$ \\
\hline 30,0 g.. $\mathrm{L}^{-1}$ & $65,31^{\mathrm{A} \mathrm{a}}$ & $22,89^{\mathrm{A} \mathrm{a}}$ & $536,21^{\mathrm{B} \mathrm{a}}$ & $625,22^{\mathrm{B} \mathrm{b}}$ \\
\hline \multicolumn{5}{|c|}{ Casa de Vegetação Sombreada $50 \%$} \\
\hline 0,0 g. $\mathrm{L}^{-1}$ & $63,87^{\mathrm{A} \mathrm{a}}$ & $21,84^{\mathrm{A} \mathrm{a}}$ & $701,14^{\mathrm{A} \mathrm{ab}}$ & $786,85^{\mathrm{A} a b}$ \\
\hline 15,0 g. $\mathrm{L}^{-1}$ & $64,53^{\mathrm{A} \mathrm{a}}$ & $20,34^{\mathrm{A} \mathrm{a}}$ & $685,30^{\mathrm{A} a}$ & $770,17^{\mathrm{A} a}$ \\
\hline 30,0 g.. $\mathrm{L}^{-1}$ & $60,75^{\mathrm{A} \mathrm{a}}$ & $23,52^{\mathrm{A} \mathrm{a}}$ & $663,38^{\mathrm{A} a b}$ & $747,65^{\mathrm{A} a b}$ \\
\hline \multicolumn{5}{|c|}{ Casa de Vegetação Sem Proteção } \\
\hline $0,0 \mathrm{~g} \cdot \mathrm{L}^{-1}$ & $64,85^{\mathrm{A} \mathrm{a}}$ & $24,54^{\mathrm{A} \mathrm{a}}$ & $735,38^{\mathrm{A} \mathrm{a}}$ & $824,78^{\mathrm{A} a}$ \\
\hline 15,0 g. $\mathrm{L}^{-1}$ & $57,51^{\mathrm{AB} \text { a }}$ & $21,48^{\mathrm{A} \mathrm{a}}$ & $812,92^{\mathrm{A} \mathrm{a}}$ & $891,91^{\text {A a }}$ \\
\hline 30,0 g... $\mathrm{L}^{-1}$ & $48,00^{\mathrm{B} \mathrm{b}}$ & $23,16^{\mathrm{A} \mathrm{a}}$ & $843,92^{\mathrm{Ab}}$ & $915,08^{\mathrm{A} \mathrm{a}}$ \\
\hline $\mathrm{CV}$ & 11,16 & 14,42 & 17,91 & 16,26 \\
\hline
\end{tabular}

* Médias seguidas pela mesma letra não diferem entre si pelo teste de Tukey a 5\%. E.Ad - Epiderme Adaxial; E.Ab - Epiderme abaxial; MESO - Mesofilo; ETL - Espessura Total do Limbo; $\mathrm{N}^{\circ}$ Feixes - Número de feixes vasculares.

A espessura do mesofilo foi maior em casa de vegetação. A sacarose em interação com a luz, resultou em tendência de menor espessura para plântulas mantidas em sala de crescimento nas maiores concentrações de sacarose, seguindo o mesmo padrão obtido para as epidermes. A espessura total do limbo seguiu o mesmo padrão dos resultados obtidos para a espessura do mesofilo (Tabela 4). De maneira similar, Lee et al. (1988), Dousseau et al. (2008) atribuíram a altas intensidades de luz um aumento no tamanho das células do mesofilo, uma maior espessura da folha, bem como a uma compactação celular mais pronunciada, em folhas cultivadas de Liquidambar. Os autores afirmaram ainda, que baixas intensidades luminosas reduzem a divisão celular, resultando em reduzida área foliar, produzindo folhas mais delgadas.

Observou-se tendência de redução nas espessuras dos tecidos foliares nas maiores concentrações de sacarose, apesar dessas diferenças não terem sido significativas. Resultados similares foram observados em Gardenia jasminoides (SERRET \& TRILLAS, 2000). Contudo, é importante ressaltar que o cultivo in vitro na ausência de sacarose pode restringir a atividade fotossintética pela baixa concentração de $\mathrm{CO}_{2}$ dentro dos frascos, sendo necessário o fornecimento adicional dele.

Pela análise dos resultados anatômicos obtidos neste experimento, evidenciam a plasticidade foliar de $C$. walkeriana, ao ambiente. Essa capacidade de alteração tem sido observada para diversas espécies estudadas em cultura de tecidos (DIMASSI-THERIOU \& BOSABALIDIS, 1997; KHAN et al., 2002; SERRET \& TRILLAS, 2000; SERRET et al., 1997). As alterações promovidas pelo ambiente podem tornar a folha semelhante àquela encontrada em ambiente natural, podendo evidenciar uma maior capacidade fotossintética.

\section{CONCLUSÕES}

Com os resultados obtidos neste experimento, conclui-se que é possível cultivar Cattleya walkeriana em luz natural, reduzindo a concentração de sacarose, observando-se a fase e os objetivos do cultivo.

\section{REFERÊNCIAS BIBLIOGRÁFICAS}

ADELBERG, J.; FUJIWARA, K.; KIRDMANEE, C.; KOZAI, T. Photoautotrophic shoot and root development for triploid melon. Plant Cell Tissue and Organ Culture, Dordrecht, v. 57, p. 95-104, 1999.

AHLOOWALIA, B. S.; SAVANGIKAR, V. A. Low costs options for energy and labour. In: Low costs options for tissue culture technology in developing countries. Austria: IAEA, 2004. p. 41-45.

ARIGITA, L.; GONZALEZ, A.; TAMÉS, R. S. Influence of $\mathrm{CO}_{2}$ and sucrose on photosynthesis and transpiration of Actinia deliciosa explants cultured in vitro. Physiologia Plantarum, Copenhagen, v. 115, p. 166-173, 2002. 
ARNON, D. I. Copper enzymes in isolated chloroplasts: plyphrenol oxidase in Beta vulgaris. Plant Physiology, Washington, v. 34, p. 1-15, 1949.

BRAGA, F. T.; PASQUAL, M.; CASTRO, E. M. DE; DIGNART, S. L.; BIAGIOTTI, G.; PORTO, J. M. P.

Qualidade de luz no cultivo in vitro de Dendranthema grandiflorum cv. Rage: características morfofisiológicas. Ciência e Agrotecnologia, Lavras, v.33, n.2, p. 502-508, mar./abr., 2009.

CHENEVARD, D.; FROSSARD, J. S.; ALLEMAND, C. J. Carbohydrate reserves and $\mathrm{CO}_{2}$ balance of hybrid walnut (Juglans nigra $\mathrm{n}^{\circ} 23 \mathrm{X}$ Juglans regia) plantlets during acclimatization. Scientia Horticulturae, Amsterdam, v. 68, n. 1, p. 53-59, 1997.

\section{CHU, E. P.; RIBEIRO, R. C. L. F. Growth and} carbohydrate changes in shoot cultures of Dioscorea species as influenced by photoperiod, exogenous sucrose and cytokinin concentrations. Plant Cell Tissue and Organ Culture, Dordrecht, v. 70, p. 241-249, 2002.

CUTTER, E. G. Plant Anatomy: experiments and interpretation. Massachusets: A. Wesley, 1971. 343 p.

DENG, R.; DONNELLY, D. In vitro hardening of red raspberry by $\mathrm{CO}_{2}$ enrichment and reduced medium sucrose concentration. HortScience, Amsterdam, v. 28, n. 10, p. 1048-1051, 1993.

DIMASSI-THERIOU, K.; BOSABALIDIS, A. M. Effects of light, magnesium and sucrose on leaf anatomy, photosynthesis, starch and total sugar accumulation, in kiwifruit cultured in vitro. Plant Cell Tissue and Organ, Dordrecht, v. 47, p. 127-134, 1997.

DOUSSEAU, S.; ALVARENGA, A. A. DE; CASTRO, E. M. DE; SOARES, R. P.; EMRICH, E. B.; MELO, L. A. DE. Anatomia foliar de Tabebuia serratifolia (Vahl) Nich. (Bignoniaceae) propagadas in vitro, in vivo e durante a aclimatização. Ciência e Agrotecnologia, Lavras, v.32, n.6, p. 1694-1700, nov./dez., 2008.

ECONOMOU, A. S.; READ, P. E. Light treatments to improve efficiency of in vitro propagation systems. Hortscience, Alexandria, v. 22, n. 5, p. 751-754, 1987.

ERIG, A. C.; SCHUCH, M. W. Micropropagação fotoautotrófica e o uso da luz natural. Ciência Rural, Santa Maria, v. 35, n. 4, p. 961-965, 2005.
GRATTAPAGLIA, D.; MACHADO, M. A. Micropropagação. In. TORRES, A. C.; CALDAS, L. S.; BUSO, J. A. (Eds.). Cultura de tecidos e transformação genética de plantas. Brasília, DF: Embrapa-SPI/EmbrapaCNPH, 1998. p. 183-260, 509 p.

IBARAKI, Y.; NOZAKI, Y. Estimation of light intensity distribution in a culture vessel. Plant Cell, Tissue and Organ Culture, Dordrecht, v. 80, p. 111-113, 2005.

KÄMPF, A. N. A floricultura brasileira em números. Revista Brasileira de Horticultura Ornamental, Campinas, v. 3, p. 1-7, 1997.

KANECHI, M.; OCHI, M.; ABE, M.; INAGAKI, N.; MAEKAWA, S. The effects of carbon dioxide enrichment, natural ventilation, and light intensity on growth, photosynthesis, and transpiration of cauliflower plantlets cultured in vitro photoautotrophically and photomixotrophically. Journal of American Society for Horticultural Science, Alexandria, v. 123, p. 176-181, 1998.

KHAN, P. S. S. V.; KOZAI, T.; NGUYEN, Q. T.; KUBOTA, C.; DHAWAN, V. Growth and net photosynthetic rates of Eucalyptus tereticornis Smith under photomixotrophic and various photoautotrophic micropropagation conditions. Plant Cell, Tissue and Organ Culture, Dordrecht, v. 71, p. 141-146, 2002.

KODYN, A.; ZAPATA-ARIAS, F. J. Natural light as an alternative light source for the in vitro culture of banana (Musa acuminate cv. 'Grand Naine1). Plant Cell Tissue and Organ Culture, Dordrecht, v. 55, p. 141-145, 1999.

KOZAI, T.; IWABUCHI, K.; WATANABE, I Photoautotrophic and photomixotrophic growth strawberry plantlets in vitro and changes in nutrient composition of the medium. Plant Cell tissue and Organ Culture, Dordrecht, v. 25, p. 107-115, 1991.

KOZAI, T.; KUBOTA, C. Developing a photoautotrophic micropropagation system for woody plants. Journal of Plant Research, [S.1.], v. 114, p. 525-537, 2001.

KOZAI, T.; WATANABE, K.; JEON, B. R. Stem elongation and growth of Solanun tuberosum $\mathrm{L}$. in vitro in response to photosynthetic photon flux, photoperiod and difference in photoperiod and dark period temperatures. Scientia Horticulturae, Copenhagen, v. 64, p. 1-9, 1995. 
KRAUS, J. E.; ARDUIM, M. Manual básico de métodos em morfologia vegetal. Seropédica: UFRRJ, 1997. 198 p.

\section{LABORIAU, L. G.; OLIVEIRA, J. G.; SALGADO-} LABORIAU, M. I. Transpiração de Schizolobium parahyba (vell) Toledo I: comportamento na estação chuvosa, nas condições de caeté, Minas Gerais. Anais da Academia Brasileira de Ciências, Rio de Janeiro, v. 33, n. 2, p. 237-252, 1961.

LEE, N.; WEZSTEIN, Y.; SOMMER, H. E. Effects of quantum flux density on photosynthesis and chloroplast ultraestructure in tissue-culture plantlets and seedlings of Liquidambar styraciflua L. towards improved acclimatization and field survival. Plant Physiology, Washington, v. 78, p. 637-641, 1985.

LEE, N.; WESZTEIN, Y.; SOMMER, H. E. Quantum flux density effects on the anatomy and surface morphology of in vitro-and in vivo developed Sweetgum Leaves. Journal of the American Society of Horticultural Science, Alexandria, v. 113, n. 1, p. 167-171, 1988.

MURASHIGE, T.; SKOOG, F. A revised medium for rapid growth and bio-assays with tobacco tissue cultures. Physiologia Plantarum, Copenhagen, v. 15, p. 473-497, 1962.

PAULA, C. C.; SILVA, H. M. P. Cultivo prático de orquídeas. 2. ed. Viçosa: UFV, 2001. 63 p.

PRAKASH, S.; HOQUE, M. I.; BRINKS, T. Culture media and containers. In: INTERNATIONALATOMIC ENERGY AGENCY. Low costs options for tissue culture technology in developing countries. Austria, 2004. p. 29-40.

RADMANN, E. B.; BRAGA, E. J. B.; KARAN, M. A. L.; POSADA, M. A. C.; PETERS, J. A. Influência da densidade de fluxo luminoso na qualidade de plantas micropropagadas de Gypsophila paniculata L. Revista Brasileira de Agrociência, Pelotas, v. 7, n. 3, p. 171-175, 2001.

REZENDE, R. K. S.; PAIVA, L. V.; PAIVA, R.; CHALFUN JÚNIOR, A.; TORGA, P. P.; CASTRO, E. M. DE. Organogênese em capítulos florais e avaliação de características anatômicas da folha de Gerbera jamesonii Adlam. Ciência e Agrotecnologia, Lavras, v.32, n.3, p.821-827, maio/jun., 2008.

SANTANA, J. R. F. DE.; PAIVA, R.; RESENDE, R. K. S.; CASTRO, E. M. DE; PEREIRA, F. D.; OLIVEIRA, L. M. Estímulo do comportamento fotoautotrófico durante o enraizamento in vitro de Annona glabra L., II. aspectos da anatomia da folha antes da aclimatização. Ciência e Agrotecnologia, Lavras, v.32, n.2, p. 640-644, mar./abr., 2008.

SAVANGIKAR, V. A. Role of low cost options in tissue culture. In: INTERNATIONALATOMIC ENERGY AGENCY. Low costs options for tissue culture technology in developing countries. Austria, 2004. p. 11-15.

SCIUTTI, R.; MORINI, S. Water loss and photosynthesis of plum plantlets is influenced by relative humidity during rooting in vitro. Journal of Horticultural Science, London, v. 70, n. 2, p. 221-228, 1995.

SERRET, M. D.; TRILLAS, M. I. Effects of light and sucrose levels on the anatomy, ultra estructure, and photosynthesis of Gardenia jasminoides leaflets cultured in vitro. International Journal of Plant Sciences, [S.1.], v. 161, n. 2, p. 281-289, 2000.

SERRET, M. D.; TRILLAS, M. I.; MATAS, J.; ARAUS, J. L. The effect of different closure types, light, and sucrose concentration on carbon isotope composition and growth of Gardenia jasminoides plantlets during the micropropagation and subsequent acclimation ex vitro. Plant Cell Tissue and Organ, Dordrecht, v. 47, p. 217-230, 1997.

SOONTORNCHAINAKSAENG, P.; CHAICHAROEN, S.; SIRIJUNTARUT, M.; KRUATRACHUE, M. In vitro studies on the effect of light intensity on plant growth of Phaius tankervilliae (Banks ex L' Herit) Bl. And Vanda coerulea Giff. ScienceAsia, [S.1.], v. 27, p. 233-237, 2001.

TORRES, A. C.; CALDAS, L. S. Cultura de tecidos e transformação genética de plantas. Brasília, DF: SPI/ Embrapa-CNPH, 1998. v. 1, 509 p.

ZANENGA-GODOY, R.; COSTA, C. G. Anatomia foliar de quatro espécies do gênero Cattleya Lindl. (Orchidaceae) do Planalto Central Brasileiro. Acta Botânica Brasileira, Brasília, v. 17, n. 1, p. 101-118, 2003. 